\title{
Temporal Variation in Diet and Nutrition of Preincubating Greater Sage-Grouse
}

\author{
Michael A. Gregg, ${ }^{1}$ Jenny K. Barnett, ${ }^{2}$ and John A. Crawford ${ }^{3}$ \\ Authors are ${ }^{1}$ Wildlife Biologist, US Fish and Wildlife Service, Mid-Columbia River National Wildlife Refuge Complex, Burbank, WA 99323, USA; \\ ${ }^{2}$ Wildlife Biologist, Confederated Tribes of the Umatilla Indian Reservation, Pendleton, OR 97801, USA; and ${ }^{3}$ Professor Emeritus, Department of \\ Fisheries and Wildlife, Oregon State University, Corvallis, OR 97331, USA.
}

\begin{abstract}
Greater sage-grouse (Centrocercus urophasianus) habitat management involves vegetation manipulations to increase or decrease specific habitat components. For sage-grouse habitat management to be most effective, an understanding of the functional response of sage-grouse to changes in resource availability is critical. We investigated temporal variation in diet composition and nutrient content (crude protein, calcium, and phosphorus) of foods consumed by preincubating female sagegrouse relative to food supply and age of hen. We collected 86 preincubating female greater sage-grouse at foraging areas during early (18-31 March) and late (1-12 April) preincubation periods during 2002-2003. Females consumed 22 food types including low sagebrush (Artemisia arbuscula Nutt.), big sagebrush (Artemisia tridentata Nutt.), 15 forb species, 2 insect taxa, sagebrush galls, moss, and a trace amount of unidentified grasses. Low sagebrush was the most common food item, but forbs were found in $89 \%$ of the crops and composed $30.1 \%$ aggregate dry mass (ADM) of the diet. ADM and species composition of female diets were highly variable between collection periods and years, and coincided with temporal variation in forb availability. Adult females consumed more forbs and less low sagebrush compared to yearling females. Because of higher levels of crude protein, calcium, and phosphorus, forbs were important diet components in comparison with low sagebrush, which had the lowest nutrient content of all foods consumed. Our results indicate that increased forb abundance in areas used by female sage-grouse prior to nesting would increase their forb consumption and nutritional status for reproduction. We recommend that managers should emphasize delineation of habitats used by preincubating sage-grouse and evaluate the need for enhancing forb abundance and diversity.
\end{abstract}

\section{Resumen}

Un mejor manejo del hábitat del urogallo (Centrocercus urophasianus) implica la manipulación de la vegetación para aumentar o disminuir algunos componentes específicos de su hábitat. La comprensión de la respuesta del urogallo a los cambios en disponibilidad de recursos es crítica para un manejo efectivo de su hábitat. Se investigó la variación temporal en la composición y el contenido de nutrientes (proteína cruda, calcio, y fósforo) de la dieta consumida por hembras en preincubación en relación con la disponibilidad de alimentos y edad de la gallina. Se colectaron 86 hembras en preincubación en áreas de alimentación al inicio (Marzo 18-31) y finales de la preincubación (Abril 1-12) durante 2002-2003. Las hembras consumieron 22 tipos del alimento incluyendo arbustos bajos (Artemisa arbuscula Nutt.) y grandes (A. tridentata Nutt.), 15 especies de hierbas, 2 tipos de insectos, arbustivas irritantes, musgos, además de una cantidad de zacates no identificados. A. arbuscula fue el alimento más común, pero la hierbas constituyeron el $89 \%$ de la muestras y 30.1\% de la materia seca acumulada (ADM) en de dieta. La ADM y la composición de especies en la dieta de las hembras fue notablemente variable entre períodos de colección y años, esto coincidió con la variación temporal en la disponibilidad de las hierbas. Las hembras adultas consumieron más hierbas y menos arbustos bajos comparados con hembras de un año. Debido a los niveles más altos de proteína cruda, calcio y fósforo, las herbáceas fueron componentes importantes en la dieta en comparación con el arbusto bajo. El arbusto bajo presentó el contenido de nutrientes más bajo de todos los alimentos consumidos. Estos resultados indican que la creciente abundancia de hierbas en las áreas habitadas por hembras de urogallo antes de la época de anidar, aumentaría el consumo de hierbas y el estado nutricional para la época de reproducción. Recomendamos que los que manejan este recurso debieran delimitar el uso del hábitat usado por hembras urogallo en preincubacion y evaluar la necesidad de incrementar la abundancia y diversidad de las herbáceas.

Key Words: calcium, Centrocercus urophasianus, crude protein, forb, phosphorus, reproduction

\section{INTRODUCTION}

Research was funded by the US Fish and Wildlife Service, Bureau of Land Management, National Fish and Wildlife Foundation, Oregon Dept of Fish and Wildlife, Nevada Division of Wildlife, Nevada Bighorns Unlimited, and Nevada Chukar Foundation.

At time of the research Gregg and Barnett were wildlife biologists, US Fish and Wildlife Service, Sheldon-Hart Mountain National Wildlife Refuge Complex, Lakeview, OR 97630, USA.

Correspondence: Michael A. Gregg, US Fish and Wildlife Service, Mid-Columbia River National Wildlife Refuge Complex, Burbank, WA 99323, USA. Email: mike_gregg@fws.gov

Manuscript received 29 February 2008; manuscript accepted 30 June 2008.
Greater sage-grouse (Centrocercus urophasianus) reproductive success is, in part, related to nutrition of females during the breeding season (Carey 1996). Grouse do not rely entirely on endogenous nutrient reserves for reproduction (Thomas and Popko 1981; Thomas 1986); they also depend on exogenous sources of nutrients (Beckerton and Middleton 1982; Thomas 1982; Moss and Watson 1984). For example, reduced productivity has been reported for captive ruffed grouse 
(Bonasa umbellus; Beckerton and Middleton 1982), willow ptarmigan (Lagopus lagopus; Hanssen et al. 1982), and other Galliformes (Breitenbach et al. 1963; Menge et al. 1979; Aboul-Ela et al. 1992) on protein-deficient diets. Similarly, egg production was reduced for Galliformes on calcium- (Greeley 1962; Chambers et al. 1966; Hinkson et al. 1970) and phosphorus- (Crowley et al. 1963; Harms et al. 1965; Cain 1982) deficient diets. Hence, nutrient content and availability of foods during breeding (March and April) may affect sagegrouse productivity (Barnett and Crawford 1994; Dunbar et al. 2005; Gregg et al. 2006).

Numerous researchers have reported that grouse select foods high in nutrient content (Gardarsson and Moss 1969; Gurchinoff and Robinson 1972; Moss 1972; King and Bendell 1982; Remington and Braun 1985). Barnett and Crawford (1994) reported that female greater sage-grouse shift their diet during spring from sagebrush and select forbs, which are high in crude protein, calcium, and phosphorus. Resource selection, however, may not always be independent of availability. Mysterud and Ims (1998) demonstrated how resource selection can differ with availability of that resource. Animals that require a certain amount of a given resource may show strong selection when it is scarce and avoidance when it is abundant (Mysterud and Ims 1998). Hence, strong animal resource selection or avoidance may not provide a direct link between the functional response of animals to changes in availability of resources (Morrison 2001).

Sage-grouse habitat management involves vegetation manipulations to increase availability of desired resources. For sagegrouse habitat management to be most effective, an understanding of the functional response of sage-grouse to changes in specific habitat components that allow sage-grouse to survive and reproduce is critical. However, information on how food supply affects consumption of food items and nutrient intake by sage-grouse is lacking. Consequently, our objective was to describe the temporal variation in diet composition and nutrient content (e.g., crude protein, calcium, and phosphorus) of foods consumed by preincubating female greater sage-grouse in relation to changes in food availability.

\section{METHODS}

\section{Study Area}

We conducted our study within the Great Basin in southeastern Oregon and northwestern Nevada. This region, bordered by the Warner Mountains to the west, was characteristic of shrubsteppe ecosystems. Topography consisted of sagebrush plains broken up by mountains, rolling hills, and table lands. Elevation ranged from $1200 \mathrm{~m}$ to $2450 \mathrm{~m}$. Annual average precipitation and average minimum and maximum temperatures ranged from $29 \mathrm{~cm}$ to $33 \mathrm{~cm}$ and from $-22^{\circ} \mathrm{C}$ to $38^{\circ} \mathrm{C}$, respectively (Western Regional Climate Center 2005). Dominant sagebrush communities included low (Artemisia arbuscula Nutt.), Wyoming (Artemisia tridentata subsp. wyomingensis Welsh.), and mountain big sagebrush (Artemisia tridentata subsp. vaseyana Rydb.). Basin big sagebrush (Artemisia tridentata subsp. tridentata Nutt.) was present in areas of deeper soils in drainage bottoms. Other common shrubs and trees included bitterbrush (Purshia tridentata [Pursh] DC.), rabbitbrush (Chrysothamnus spp. Nutt.), aspen (Populus tremuloides Michx.), western juniper (Juniper occidentalis Hook.), and curl-leaf mountain-mahogany (Cercocarpus ledifolius Nutt.).

We conducted research on three sites: Sheldon National Wildlife Refuge (NWR) in Nevada, and Hart Mountain National Antelope Refuge (NAR) and Beatys Butte in Oregon. Sheldon NWR and Hart Mountain NAR were administered by the US Fish and Wildlife Service and encompassed 232294 ha and 114375 ha, respectively. Beatys Butte was administered by the Bureau of Land Management and encompassed $110682 \mathrm{ha}$. These areas were $>40 \mathrm{~km}$ apart and were selected because they were representative of the northern Great Basin, they were accessible during spring, and considerable long-term data on sage-grouse habitat use and productivity were available from previous research (Gregg 1991; Barnett 1992; Drut 1992; Coggins 1998; Byrne 2002; Davis 2002).

Low sagebrush communities associated with lek sites and nesting areas were the primary foraging areas used by preincubating females on our study area (Barnett and Crawford 1994; Gregg 2006). Low sagebrush on our study area typically occurred in large homogenous stands consisting of several thousand hectares. Grasses in low sagebrush consisted largely of bluegrass (Poa spp. L.) and bluebunch wheatgrass (Pseudoroegneria spicata [Pursh] A. Löve). Common annual and perennial forbs included mountain dandelion (Agoseris spp. Raf.), balsamroot (Balsamorhiza spp. Nutt.), blue-eyed Mary (Collinsia paviflora Lindl.), buckwheat (Eriogonum spp. Michx.), buttercup (Ranunculus spp. L), clover (Trifolium spp. L.), desert-parsley (Lomatium spp. L.), hawksbeard (Crepis spp. L.), milk-vetch (Astragalus spp. L.), everlasting (Antennaria spp. Gaertner), and phlox (Phlox spp. L.).

\section{Experimental Design and Data Collection}

We collected preincubating female greater sage-grouse with shotgun within known foraging areas at each study site during 20 March-12 April 2002 and 18 March-10 April 2003. Annual variation in nesting chronology is low on our study area and peak breeding of females occurs at the end of March in this region of the Great Basin (Gregg 2006), so we grouped female collections into two 12-d periods (early and late) each year. These two collection periods represented the pre- and postbreeding periods before initiation of incubation. We identified foraging areas from past (Gregg 1991; Barnett 1992; Coggins 1998; Byrne 2002; Davis 2002) and concurrent (Gregg 2006) radiotelemetry studies of female sage-grouse. We collected females during the evening or shortly after dusk (1700-2130 hours) with the aid of bird dogs or spotlights to increase the likelihood of obtaining birds with full crops. To obtain a representative sample of the female grouse population, we attempted to collect the first female encountered during each collection event. Collection sites were flagged and recorded as Universal Transverse Mercator coordinates to facilitate plot location for later vegetation sampling. We used molt patterns of primaries (Crunden 1963) to assign age (adult or yearling) to collected females and removed crop, ventriculus, and ovaries. We identified plant species in crops and weighed ovaries to the nearest $0.01 \mathrm{~g}$ to assess breeding status. Crop and ventriculus contents were placed in separate plastic bags and 
frozen. Female collection protocol was approved by the Oregon State University Laboratory Animal Resource Center (Animal Care and Use permit number 2702) and conducted under state scientific collection permits from Oregon (permit number 015-03) and Nevada (permit number 22139).

We measured species composition of female diets in two ways. First, frequency of occurrence was calculated by dividing the number of crops in which each food item was found by total number of crops examined. Second, crop contents were sorted by species, dried at $50^{\circ} \mathrm{C}$ to constant weight, and weighed to the nearest $0.001 \mathrm{~g}$. We calculated percentage of aggregate dry mass (ADM) of each food item identified in the crop of each female and averaged across females (Swanson et al. 1974).

We estimated availability of forbs within foraging areas during each collection period. Female collection sites and locations where females were flushed within foraging areas but not collected were used as vegetation sampling sites. We defined a sampling site as a circle with a 10-m radius centered at a female's first observed location (Barnett and Crawford 1994). We estimated cover to the nearest percent and frequency of forbs (genus or species) in $1020 \times 50 \mathrm{~cm}$ random plots within the sampling site (Daubenmire 1959). Forbs with $<1 \%$ cover were recorded as $0.5 \%$. Frequency of forbs was recorded in three $(10 \times 10 \mathrm{~cm}, 40 \times 50 \mathrm{~cm}$, and $80 \times 50 \mathrm{~cm})$ nested frames (Hironaka 1985).

We collected samples of primary shrubs and forbs consumed by grouse immediately after cover and frequency data were collected. Primary shrubs and forbs were those with $>15 \%$ frequency of occurrence in crops. Plant samples were dried at $50^{\circ} \mathrm{C}$ to constant weight. We randomly combined individual samples of primary plant species into 10 -g composite samples for nutrient analyses each year. The number of composite samples for each food type was dependent on total dry mass of plant material collected each year. Large samples were difficult to obtain for some forbs; therefore, the number of composite samples varied by species and year of collection.

We measured nutrient content (crude protein, calcium, and phosphorus) of all primary plants consumed by preincubating females. Crop and ventriculus contents of each female were analyzed separately for crude protein content. Nutrient analyses of plant samples, crop contents, and ventriculus contents followed methods described by Barnett and Crawford (1994) and were conducted by the Wildlife Habitat Laboratory, Washington State University, Pullman, Washington. We estimated crude protein content of the diet (i.e., index for dietary protein) for each female by averaging crude protein values of crop and ventriculus contents.

\section{Data Analysis}

We used generalized linear mixed models (GLMM) to evaluate temporal variation (collection periods and years) in ADM of food types (low sagebrush and forbs) in the diet of preincubating adult and yearling females. We also used GLMM to evaluate temporal variation in availability of food types at foraging areas. We included study site as a random effect in our analyses to account for possible differences in diet and nutrition of preincubating females across the study area. Inclusion of study site as a random effect allowed for inference to the entire study area and not specifically to the individual sites. We also considered a two-way interaction for collection period and year in our analyses. We used PROC MIXED (SAS 2001, version 8.2) to estimate our GLMM models. When evaluation of residual and box plots indicated unequal variances for error terms, we partitioned the variances associated with the main effects in our model using the REPEATED statement and the Kenward-Rogers option for degrees of freedom (SAS 2001, version 8.2). We considered tests significant at $\alpha<0.1$. We reported all means $( \pm \mathrm{SE})$.

\section{RESULTS}

We analyzed crops of 86 preincubating female sage-grouse and 75 (51 adults and 24 yearlings) contained food. Thirty-one (9 during early and 22 during late collection periods) and 44 (20 during early and 24 during late collection periods) females were collected in 2002 and 2003, respectively. We sampled vegetation and collected plants at 110 locations: 48 (11 during early and 37 during late collection periods) and 62 (26 during early and 36 during late collection periods) sites in 2002 and 2003, respectively.

\section{Diet Composition of Females}

Females consumed 22 different food types, including low and big sagebrush, 15 different forbs, 2 insect taxa, sagebrush galls, moss, and unidentified grasses. Low sagebrush was found in $97 \%(73 / 75)$ of crops and accounted for $65.7 \pm 3.8 \%$ ADM of the diet. Forbs occurred in $89 \%$ of crops and comprised $30.1 \pm 3.6 \% \mathrm{ADM}$ of the diet $(22.4 \pm 5.5 \%$ in 2002 and $35.6 \pm 4.5 \%$ in 2003). The most common forbs found in female crops $(>15 \%$ frequency) included everlasting (Antennaria dimorpha [Nutt.] Torr. and Gray), hawksbeard, desertparsley, mountain dandelion, sagebrush buttercup (Ranunculus glaberrimus Hook.), long-leaf phlox (Phlox longifolia Nutt.), big-head clover (Trifolium macrocephalum [Pursh] Poir.), and obscure milk-vetch (Astragalus obscurus S. Wats.) and comprised $81.7 \pm 3.8 \% \mathrm{ADM}$ of the forb diet and $29.0 \pm 3.5 \%$ $\mathrm{ADM}$ of the total diet. As a group, these forbs were consistently consumed by females across collection periods and years, except during the early period in 2002 when only four forb species were consumed in small amounts and sagebrush comprised $97.7 \pm 1.3 \% \mathrm{ADM}$ of the diet (Table 1). Insects, sagebrush galls, moss, and grass were incidental and found in trace amounts.

\section{Temporal Variation in Diet and Nutrition of Females}

Annual Variation. Only five yearling females were collected in 2002, all during the late collection period. Hence, our analyses of ADM, crude protein intake, and ovary weight between years were restricted to adult females. Adult females consumed substantially more forbs $\left(\mathrm{F}_{1,34.3}=15.21, P=0.0004\right)$ and less low sagebrush $\left(\mathrm{F}_{1,33.1}=15.91, \quad P=0.0003\right)$ during 2003 compared with 2002 (Table 1), which was concordant with greater forb availability in 2003 (frequency: $F_{1,104}=16.08$, $P=0.0001$; cover: $\mathrm{F}_{1,104}=7.22, P=0.008$; Table 2 ). Ovary development was also advanced in 2003; during the early collection period adult ovaries weighed $8.9 \pm 2.0 \mathrm{~g}$ during 
Table 1. Aggregate percent dry mass (mean $\pm \mathrm{SE}$ ) of primary shrubs and forbs ${ }^{1}$ consumed by adult and yearling preincubating greater sage-grouse collected during early (18-31 March) and late (1-12 April) collection periods in Oregon and Nevada, 2002-2003.

\begin{tabular}{|c|c|c|c|c|c|c|}
\hline \multirow[b]{3}{*}{ Food } & \multicolumn{4}{|c|}{ Adults } & \multirow{2}{*}{\multicolumn{2}{|c|}{$\begin{array}{c}\text { Yearlings } \\
2003\end{array}$}} \\
\hline & \multicolumn{2}{|c|}{2002} & \multicolumn{2}{|c|}{2003} & & \\
\hline & Early $(n=9)$ & Late $(n=17)$ & Early $(n=11)$ & Late $(n=14)$ & Early $(n=9)$ & Late $(n=10)$ \\
\hline Low sagebrush & $97.7 \pm 1.3$ & $64.3 \pm 8.4$ & $50.2 \pm 11.3$ & $50.4 \pm 7.5$ & $73.0 \pm 11.1$ & $74.5 \pm 6.6$ \\
\hline Forbs & $2.0 \pm 1.3$ & $25.9 \pm 7.8$ & $42.7 \pm 10.4$ & $41.5 \pm 7.4$ & $25.1 \pm 10.0$ & $24.0 \pm 6.6$ \\
\hline Everlasting & 0 & $6.7 \pm 4.0$ & $31.5 \pm 10.6$ & $6.5 \pm 3.3$ & $11.9 \pm 7.5$ & $8.8 \pm 4.7$ \\
\hline Hawksbeard & 0 & $3.0 \pm 1.4$ & $2.7 \pm 1.2$ & $23.2 \pm 7.0$ & $0.2 \pm 0.1$ & $5.0 \pm 1.8$ \\
\hline Desert-parsley & $1.8 \pm 1.1$ & $6.3 \pm 4.7$ & $3.3 \pm 1.6$ & $5.6 \pm 2.3$ & $2.6 \pm 1.3$ & $3.3 \pm 2.1$ \\
\hline Mountain dandelion & $0.02 \pm 0.02$ & $5.4 \pm 3.9$ & $1.1 \pm 0.3$ & $1.5 \pm 0.5$ & $0.3 \pm 0.2$ & $3.8 \pm 2.1$ \\
\hline Sagebrush buttercup & $0.2 \pm 0.2$ & $1.4 \pm 0.9$ & $2.8 \pm 1.9$ & $2.9 \pm 1.4$ & $0.6 \pm 0.3$ & $2.3 \pm 1.7$ \\
\hline Long-leaf phlox & $0.01 \pm 0.01$ & $0.1 \pm 0.1$ & $0.9 \pm 0.7$ & $0.1 \pm 0.1$ & $9.4 \pm 9.4$ & $0.02 \pm 0.01$ \\
\hline Big-head clover & 0 & $2.5 \pm 2.0$ & $0.3 \pm 0.2$ & $0.8 \pm 0.5$ & $0.1 \pm 0.1$ & $0.3 \pm 0.3$ \\
\hline Obscure milk-vetch & 0 & $0.5 \pm 0.2$ & $0.07 \pm 0.06$ & $0.8 \pm 0.4$ & 0 & $0.4 \pm 0.3$ \\
\hline
\end{tabular}

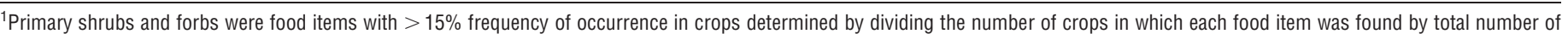
crops examined.

2003 compared with $1.7 \pm 0.3 \mathrm{~g}$ in 2002 . However, nutrient content of forbs and sagebrush was higher in 2002 compared to 2003 (Table 3), which corresponded with greater crude protein intake by adult females in 2002. Adult female crop contents averaged $20.2 \pm 1.1 \%$ crude protein during 2002 compared with $16.8 \pm 0.5 \%$ crude protein in 2003. Overall, low sagebrush had the lowest crude protein, calcium, and phosphorus content of all food plants analyzed during both years and everlasting had the lowest crude protein and phosphorus content of all primary forbs (Table 3 ).

Seasonal Variation. During 2002, adult females consumed more forbs $\left(\mathrm{F}_{1,17.9}=9.68, P=0.006\right)$ and less low sagebrush $\left(\mathrm{F}_{1,17.8}=16.57, P=0.0007\right)$ during the late compared with the early collection period (Table 1), which was concordant with greater forb availability (frequency: $\mathrm{F}_{1,44.3}=10.61, P=0.002$; cover: $F_{44.2}=8.13, P=0.007$; Table 2 ) and higher crude protein content of the diet (early: $16.7 \pm 1.6 \%$ vs. late: $22.1 \pm 1.2 \%)$. Ovary weights also increased dramatically in the late collection period $(17.7 \pm 2.7 \mathrm{~g})$ compared to the early collection period $(1.7 \pm 0.3 \mathrm{~g})$.
During 2003, consumption of forbs and low sagebrush was similar between collection periods for adult and yearling females (Table 1). However, adult females consumed more forbs $\left(\mathrm{F}_{1,34.7}=3.22, \quad P=0.08\right)$ and less low sagebrush $\left(\mathrm{F}_{1,35}=6.29, P=0.017\right)$ than yearling females during both collection periods (Table 1). Forb species composition of the diet differed between collection periods for adult females, but changed little for yearling females (Table 1). Everlasting was the primary forb in adult and yearling crops during the early collection period (Table 1). Hawksbeard showed a 3.5-fold increase in frequency and 10-fold increase in cover in the late compared to the early collection period (Table 2) and was the primary forb in adult female crops during the late collection period. Everlasting availability did not change during the late collection period (Table 2) and remained the primary forb found in yearling female crops (Table 1). Crude protein content of the diet was similar between adult $(15.1 \pm 0.4 \%)$ and yearling $(15.1 \pm 1.1 \%)$ females during the early collection period. However, during the late collection period crude protein content of the diet increased for adults $(18.1 \pm 0.7 \%)$, but changed little for yearlings $(16.0 \pm 0.4 \%)$. Ovary develop-

Table 2. Availability (\% frequency and \% cover; mean $\pm \mathrm{SE}$ ) of primary forbs ${ }^{1}$ consumed by preincubating greater sage-grouse at foraging areas during early (18-31 March) and late (1-12 April) collection periods in Oregon and Nevada, 2002-2003.

\begin{tabular}{|c|c|c|c|c|c|c|c|c|}
\hline \multirow[b]{3}{*}{ Food } & \multicolumn{4}{|c|}{2002} & \multicolumn{4}{|c|}{2003} \\
\hline & \multicolumn{2}{|c|}{ Early $(n=11)$} & \multicolumn{2}{|c|}{ Late $(n=37)$} & \multicolumn{2}{|c|}{ Early $(n=26)$} & \multicolumn{2}{|c|}{ Late $(n=36)$} \\
\hline & Frequency & Cover & Frequency & Cover & Frequency & Cover & Frequency & Cover \\
\hline Forbs & $6.9 \pm 1.1$ & $0.7 \pm 0.2$ & $13.0 \pm 1.3$ & $2.6 \pm 0.6$ & $13.5 \pm 1.6$ & $2.3 \pm 0.5$ & $17.3 \pm 1.4$ & $3.4 \pm 0.6$ \\
\hline Everlasting & $1.2 \pm 0.3$ & $0.1 \pm 0.03$ & $0.9 \pm 0.2$ & $0.2 \pm 0.1$ & $2.1 \pm 0.4$ & $0.3 \pm 0.1$ & $1.8 \pm 0.4$ & $0.3 \pm 0.1$ \\
\hline Hawksbeard & 0 & 0 & $1.6 \pm 0.4$ & $0.2 \pm 0.1$ & $0.6 \pm 0.2$ & $0.02 \pm 0.01$ & $2.1 \pm 0.4$ & $0.2 \pm 0.1$ \\
\hline Desert-parsley & $2.0 \pm 0.7$ & $0.2 \pm 0.2$ & $2.7 \pm 0.5$ & $0.9 \pm 0.4$ & $4.0 \pm 0.8$ & $1.3 \pm 0.5$ & $4.2 \pm 0.6$ & $1.7 \pm 0.5$ \\
\hline Mountain dandelion & $0.4 \pm 0.3$ & $0.02 \pm 0.02$ & $2.2 \pm 0.4$ & $0.3 \pm 0.1$ & $1.8 \pm 0.4$ & $0.2 \pm 0.04$ & $2.1 \pm 0.4$ & $0.2 \pm 0.1$ \\
\hline Sagebrush buttercup & $1.1 \pm 0.5$ & $0.1 \pm 0.05$ & $1.9 \pm 0.4$ & $0.2 \pm 0.1$ & $1.6 \pm 0.4$ & $0.1 \pm 0.04$ & $2.0 \pm 0.4$ & $0.2 \pm 0.1$ \\
\hline Long-leaf phlox & $2.1 \pm 0.6$ & $0.2 \pm 0.1$ & $1.7 \pm 0.3$ & $0.1 \pm 0.02$ & $2.4 \pm 0.4$ & $0.2 \pm 0.1$ & $2.6 \pm 0.4$ & $0.3 \pm 0.1$ \\
\hline Big-head clover & 0 & 0 & $1.4 \pm 0.5$ & $0.6 \pm 0.3$ & $0.2 \pm 0.1$ & $0.01 \pm 0.01$ & $1.4 \pm 0.5$ & $0.3 \pm 0.1$ \\
\hline Obscure milk-vetch & $0.1 \pm 0.1$ & $0.03 \pm 0.03$ & $0.6 \pm 0.2$ & $0.1 \pm 0.04$ & $0.9 \pm 0.3$ & $0.1 \pm 0.04$ & $1.2 \pm 0.3$ & $0.2 \pm 0.05$ \\
\hline
\end{tabular}

${ }^{1}$ Primary forbs were species with $>5 \%$ frequency of occurrence in crops determined by dividing the number of crops in which each food item was found by total number of crops examined. 
Table 3. Nutrient content (mean $\pm \mathrm{SE}$ ) of primary shrubs and forbs ${ }^{1}$ consumed by pre-incubating greater sage-grouse. Plant samples were collected at foraging areas during March and April, 2002-2003, Oregon and Nevada, USA.

\begin{tabular}{|c|c|c|c|c|c|c|c|c|}
\hline \multirow[b]{2}{*}{ Food } & \multicolumn{2}{|c|}{$\begin{array}{c}\text { No. of } \\
\text { samples }\end{array}$} & \multicolumn{2}{|c|}{ Crude protein (\%) } & \multicolumn{2}{|c|}{ Calcium (\%) } & \multicolumn{2}{|c|}{ Phosphorus (\%) } \\
\hline & 2002 & 2003 & 2002 & 2003 & 2002 & 2003 & 2002 & 2003 \\
\hline Low sagebrush & $15^{2}$ & 15 & $16.2 \pm 0.5$ & $12.0 \pm 0.1$ & $0.50 \pm 0.01$ & $0.40 \pm 0.01$ & $0.29 \pm 0.01$ & $0.23 \pm 0.01$ \\
\hline Forbs & 60 & 76 & $28.4 \pm 0.6$ & $24.5 \pm 0.6$ & $0.96 \pm 0.05$ & $0.75 \pm 0.03$ & $0.54 \pm 0.02$ & $0.53 \pm 0.01$ \\
\hline Everlasting & 3 & 9 & $18.7 \pm 1.6$ & $16.6 \pm 0.5$ & $0.74 \pm 0.04$ & $0.75 \pm 0.02$ & $0.37 \pm 0.01$ & $0.39 \pm 0.01$ \\
\hline Hawksbeard & 13 & 13 & $30.9 \pm 0.6$ & $25.7 \pm 0.7$ & $0.98 \pm 0.08$ & $0.77 \pm 0.06$ & $0.61 \pm 0.04$ & $0.53 \pm 0.01$ \\
\hline Desert-parsley & 14 & 15 & $27.5 \pm 1.1$ & $26.0 \pm 0.9$ & $1.42 \pm 0.10$ & $1.14 \pm 0.07$ & $0.59 \pm 0.03$ & $0.58 \pm 0.03$ \\
\hline Mountain dandelion & 7 & 10 & $29.4 \pm 1.0$ & $25.7 \pm 0.8$ & $0.61 \pm 0.03$ & $0.57 \pm 0.03$ & $0.61 \pm 0.03$ & $0.54 \pm 0.02$ \\
\hline Sagebrush buttercup & 8 & 15 & $23.0 \pm 0.6$ & $20.8 \pm 0.6$ & $0.52 \pm 0.03$ & $0.47 \pm 0.02$ & $0.50 \pm 0.03$ & $0.49 \pm 0.02$ \\
\hline Long-leaf phlox & $7^{3}$ & 9 & $28.8 \pm 1.5$ & $26.7 \pm 1.0$ & $0.82 \pm 0.05$ & $0.88 \pm 0.03$ & $0.49 \pm 0.03$ & $0.56 \pm 0.01$ \\
\hline Big-head clover & 6 & 3 & $35.2 \pm 2.1$ & $40.2 \pm 0.1$ & $1.23 \pm 0.06$ & $0.52 \pm 0.01$ & $0.44 \pm 0.03$ & $0.64 \pm 0.01$ \\
\hline Obscure milk-vetch & 2 & 2 & $29.6 \pm 0.5$ & $30.5 \pm 1.0$ & $0.62 \pm 0.11$ & $0.48 \pm 0.09$ & $0.43 \pm 0.05$ & $0.48 \pm 0.03$ \\
\hline
\end{tabular}

${ }^{1}$ Primary shrubs and forbs were food items with $>15 \%$ frequency of occurrence in crops determined by dividing the number of crops in which each food item was found by total number of crops examined.

${ }^{2}$ Fourteen samples of sagebrush were analyzed for calcium and phosphorus during 2002.

${ }^{3}$ Six samples of long-leaf phlox were analyzed for calcium and phosphorus during 2002.

ment was similar between age classes (adult early: $8.9 \pm 2.0 \mathrm{~g}$ and adult late: $19.2 \pm 2.5 \mathrm{~g}$; yearling early: $7.0 \pm 2.6 \mathrm{~g}$ and yearling late: $15.1 \pm 3.4 \mathrm{~g}$ ).

\section{DISCUSSION}

Our results demonstrated a functional response by sagegrouse to changes in resource availability. Consumption of forbs by females increased within and between years relative to changes in forb frequency and cover. We identified a small group of forbs that were consistently consumed across collection periods and years and included hawksbeard, desert-parsley, mountain dandelion, everlasting, sagebrush buttercup, long-leaf phlox, obscure milk-vetch, and big-head clover. Except for sagebrush buttercup, these forbs were among the most-selected food items of prelaying female sagegrouse identified from previous research in Oregon (Barnett and Crawford 1994). Sage-grouse may shift dietary patterns during spring to increase intake of nutrients (i.e., select highnutrient foods) or simply because forbs are more succulent, palatable, and digestible than sagebrush (Rosentreter 2005). Regardless of the mechanism responsible for the shift in diet, consumption of forbs increased dietary intake of crude protein, calcium, and phosphorus during both years of our study because forbs consistently had higher nutrient content than sagebrush.

Reduced availability and consumption of forbs during 2002 were likely related to late winter snow that covered our study area during the early collection period and delayed forb growth. In contrast, our study area was snow-free during the early collection period in 2003, forb phenology was advanced, and availability and consumption of forbs was greater than we observed in 2002. The amount of forbs consumed by preincubating females during 2003 did not change between collection periods, but the species composition of forbs in the diet differed, particularly for adults. Consumption of everlasting decreased and other forbs, primarily hawksbeard, increased during the late collection period and was concordant with changes in availability of these individual forb species. There is little information about the relationship between consumption of preferred foods and food supply for sage-grouse. However, Naylor and Bendell (1989) reported female spruce grouse (Falcipennis canadensis) that consumed the most-preferred foods had the greatest dietary intake of crude protein, calcium, and phosphorus, and the rate of intake was correlated with the availability of preferred foods on spring territories.

We found that nutrient content of low sagebrush and forbs consumed by sage-grouse varied temporally. Amount of crude protein in female crop contents was lower during 2003 than during 2002, irrespective of greater ADM of forbs in crops during 2003, likely because of lower crude protein content of both low sagebrush and forbs. Nutrient content of forage can be directly or indirectly affected by environmental factors including weather, soil, plant competition, and grazing (Laycock and Price 1970). Although crude protein intake was presumably greater in 2002, diet quality was likely improved during 2003 because of greater forb consumption. Sagebrush leaves contain volatile chemicals (i.e., monoterpenes) that reduce palatability and digestibility (Rosentreter 2005). Monoterpenes found in sagebrush have antibacterial properties that may reduce symbiotic bacteria in the caeca of sage-grouse (Remington and Braun 1985) and concentrations of monoterpenes in sagebrush leaves are highest during spring (Cedarleaf et al. 1983). Grouse increase food intake in preparation for egg production (Savory 1975; Williams et al. 1980; Delahay and Moss 1996), but reproductive success may depend more on food quality than quantity (Moss 1969). Sage-grouse require an absolute amount of nutrients for reproduction. Although sagegrouse could increase consumption of sagebrush to meet nutritional requirements, greater forb availability in 2003 likely provided more forage of higher quality (i.e., palatable and digestible) than sagebrush and enhanced maternal nutrition of females.

Follicle development was advanced in adult females during 2003 compared to 2002, which may have been linked to greater availability and consumption of forbs. Grouse have low fat reserves and follicles must develop rapidly from exogenous 
nutrients (Thomas 1986; Carey 1996). Follicle development is likely regulated quickly by the amount and quality of food ingested and when high-quality food is abundant follicular activity increases (Thomas 1986). Thomas (1986) hypothesized that follicle enlargement and foraging behaviors must be synchronized precisely with increased food production in the habitat. Our results provide support for this hypothesis, but the biological significance for sage-grouse is unknown. Follicle development was similar for adult and yearling females during 2003 despite differences in diet composition. Sagebrush alone may provide adequate nutrition for sage-grouse clutch development. However, consumption of higher quality forage may allow for larger clutch size (Breitenbach et al. 1963; Beckerton and Middleton 1982; Aboul-Ela et al. 1992), faster clutch development, and the ability to renest if the first nest is lost, which could lead to greater reproductive success.

Sage-grouse chick survival on our study area was greater during 2003 compared with 2002 (Gregg 2006) and coincided with the year of greatest forb availability and consumption by females. We hypothesize that difference in observed chick survival between years may have been related to increased availability and consumption of forbs by females during spring 2003. Barnett and Crawford (1994) reported that annual differences in greater sage-grouse reproductive success positively corresponded with increased consumption of forbs by prelaying females. Similarly, sage-grouse renesting rates (Gregg et al. 2006) and chick survival (Dunbar et al. 2005) were related to preincubating female total plasma protein values, an index of dietary protein (Amand 1986). However, the nutritional requirements of breeding female sage-grouse and the role of forbs in preincubating female diets relative to reproductive success are unknown. The relationship between maternal nutrition and reproductive success is difficult to ascertain in free-ranging sage-grouse populations because other factors can influence success of reproduction irrespective of maternal nutrition (Drut et al. 1994; Gregg et al. 1994, 2006; Sveum et al. 1998). For example, annual productivity indices for the Oregon portion of our study area revealed fewer chicks per female in the fall harvest of 2003 compared to 2002 (Hagen 2005). The discrepancy between our observed chick survival rates and the productivity indices were likely related to reduced nest success during 2003. Observed nest success of radiomarked females was $44 \%$ during 2002 , but only $12 \%$ during 2003 (M.A. Gregg, unpublished data, 2003).

Our results suggest that diet composition of preincubating females was dependent on female age. Adult females consumed more forbs and less low sagebrush compared with yearlings during both collection periods in 2003. Interestingly, crude protein content of the diet was similar for adult and yearling females during the early collection period even though consumption of forbs by adult females was twice that of yearling females. We attributed this discrepancy to changes in forb species composition of adult female diets between collection periods. During the early collection period the primary forb consumed by adult and yearling females was everlasting, which had a crude protein content similar to low sagebrush. During the late collection period, yearling females continued to consume everlasting while adults shifted to hawksbeard, which had a much greater crude protein content than sagebrush.
Age-related differences in foraging proficiency have been documented in many species of birds (Wunderle 1991), but little research has been conducted on grouse. In contrast to our results, food habits of adult and yearling spruce grouse (Naylor and Bendell 1989) and sooty grouse (Dendragapus fuliginosus, King and Bendell 1982) in Canada were similar during spring. Differences in diet composition between adult and yearling sage-grouse during our study may have been related to differences in breeding chronology. Yearling females typically attend leks and nest later in the spring than adults (Gregg et al. 2006), which could also influence dietary patterns. However, ovary development was similar between age classes and radiomarked yearling sage-grouse had lower nest and renest initiation, nest and renest success, and brood survival compared with radio-marked adults on our study area during 2003 (Gregg 2006; Gregg et al. 2006). We surmise that greater consumption of forbs by adults could partially explain differences in observed reproductive success between age classes. However, other factors may cause differences in productivity between adult and yearling sage-grouse including social constraints, breeding experience, reproductive effort, and differential survival rates between age classes (Hannon et al. 1982; Martin 1985; Forslund and Pärt 1995). We caution that our dietary analysis between age classes was limited to a single year. Nevertheless, our results warrant further research to elucidate relationships among diet composition, nutrition, age of females, and reproductive success.

\section{MANAGEMENT IMPLICATIONS}

Our findings indicated that increasing forb availability in forbdeficient areas used by preincubating female greater sagegrouse will likely increase forb consumption and nutrient intake. Restoration techniques that may increase forb abundance in sagebrush stands include prescribed fire, mechanical treatment (e.g., brush-beating), and chemical application (Pyle and Crawford 1996; Connelly et al. 2000; Wrobleski and Kauffman 2003; Crawford et al. 2004; Dahlgren et al. 2006). Techniques that do not eliminate sagebrush cover may be the most appropriate (Dahlgren et al. 2006). Not all degraded areas require active restoration to increase forb abundance. In some cases, adjustment of timing and intensity of grazing or elimination of detrimental activities may be all that is necessary to increase forb availability during spring. Restoration projects in areas where forb abundance is at the site's ecological potential or where exotic plants dominate the understory are unlikely to be successful. Therefore, the project area should be evaluated to identify limiting factors and the likelihood of achieving project objectives before restoration projects are initiated. Selection of the appropriate restoration technique is site-specific, and we recommend that habitat restoration activities follow guidelines described in Connelly et al. (2000). In addition, it is critical that sage-grouse seasonal-use areas are identified because restoration projects that reduce sagebrush cover can be detrimental, particularly in nesting and wintering areas (Connelly et al. 2000).

Seeding may be required to reestablish forbs important for preincubating females in some areas. We identified a small group of early-season forbs in the Chichorieae (dandelion) tribe within 
the family Compositae, and members of the families Umbelliferae and Leguminosae that accounted for most of the high-nutrient food consumed by females. Specifically, if seed sources are available we recommend hawksbeard, desert-parsley, mountain dandelion, sagebrush buttercup, long-leaf phlox, big-head clover, everlasting, and obscure milk-vetch for habitat restoration projects that require seeding within the northern Great Basin.

\section{ACKNOWLEDGMENTS}

We thank J. Ballard, US Fish and Wildlife Service, and numerous field technicians and volunteers for assistance with data collection. We wish to acknowledge logistic and technical support provided by J. T. Forbes of the Bureau of Land Management and J. Lane of the Beatys Butte Grazing Association. C. Braun, F. Guthery, R. Moss, M. D. Pope, D. Roby, and two anonymous reviewers provided comments on earlier versions of this manuscript.

\section{LITERATURE CITED}

Aboul-Ela, S., H. R. Wilson, and R. H. Harms. 1992. The effects of dietary protein level on the reproductive performance of bobwhite hens. Poultry Science 71:1196-1200.

Amand, W. B. 1986. Avian clinical hematology and blood chemistry. In: M. E. Fowler [ED.]. Zoo and wild animal medicine. 2nd ed. Philadelphia, PA, USA: W. B. Saunders Company. p. 264-276.

BARnetT, J. K. 1992. Diet and nutrition of female sage grouse during the pre-laying period [thesis]. Corvallis, OR, USA: Oregon State University. $46 \mathrm{p}$.

Barnett, J. K., and J. A. Crawford. 1994. Pre-laying nutrition of sage grouse hens in Oregon. Journal of Range Management 47:114-118.

Beckerton, P. R., and A. L. A. Middleton. 1982. Effects of dietary protein levels on ruffed grouse reproduction. Journal of Wildlife Management 46:569-579.

Breitenbach, R. P., C. L. Nagra, and R. K. Meyer. 1963. Effect of limited food intake on cyclic annual changes in ring-necked pheasant hens. Journal of Wildlife Management 27:24-36.

BrRne, M. W. 2002. Habitat use by female greater sage grouse in relation to fire at Hart Mountain National Antelope Refuge, Oregon [thesis]. Corvallis, OR, USA: Oregon State University. $50 \mathrm{p}$.

CAlN, J. R. 1982. The effects of varying dietary phosphorus on breeding bobwhites. Journal of Wildlife Management 46:1061-1065.

Carey, C. 1996. Female reproductive energetics. In: C. Carey [ed.]. Avian energetics and nutritional ecology. New York, NY, USA: Chapman Hall, International Thomson Publishing. p. 324-374.

Cedarleaf, J. D., B. L. Welch, and J. D. Brotherson. 1983. Seasonal variation of monoterpenoids in big sagebrush (Artemisia tridentata). Journal of Range Management 36:492-494.

Chambers, G. D., K. C. Sadler, and R. P. Breitenbach. 1966. Effects of dietary calcium on egg production and bone structure of pheasants. Journal of Wildlife Management 30:65-73.

CogGins, K. A. 1998. Relationship between habitat changes and productivity of sage grouse at Hart Mountain National Antelope Refuge, Oregon [thesis]. Corvallis, OR, USA: Oregon State University. $61 \mathrm{p}$.

Connelly, J. W., M. A. Schroeder, A. R. Sands, and C. E. Braun. 2000. Guidelines for management of sage grouse populations and habitat. Wildlife Society Bulletin 28:967-985.

Crawford, J. A., R. A. Olson, N. E. West, J. C. Mosley, M. A. Schroeder, T. D. Whitson, R. F. Miller, M. A. GRegG, AND C. S. Boyd. 2004. Ecology and management of sage-grouse habitat. Journal of Range Management 57:2-19.

Crowley, T. A., A. A. Kurmick, and B. L. Reid. 1963. Dietary phosphorus for laying hens. Poultry Science 42:758.

Crunden, C. W. 1963. Age and sex of sage grouse from wings. Journal of Wildlife Management 27:846-849.
Dahlgren, D. K., R. Chi, and T. A. Messmer. 2006. Greater sage-grouse response to sagebrush management in Utah. Wildlife Society Bulletin 34:975-985.

DaubenmiRe, R. F. 1959. A canopy-coverage method of vegetation analysis. Northwest Science 33:224-227.

Davis, D. M. 2002. Breeding season habitat use and response to management activities by greater sage-grouse on Sheldon National Wildlife Refuge, Nevada [thesis]. Corvallis, OR, USA: Oregon State University. $134 \mathrm{p}$.

Delahay, R. J., and R. Moss. 1996. Food intake, weight changes, and egg production in captive red grouse before and during laying: effects of the parasitic nematode Trichostrongylus tenuis. Condor 98:501-511.

DRUT, M. S. 1992. Habitat use and selection by sage grouse brood in southeastern Oregon [thesis]. Corvallis, OR, USA: Oregon State University. 44 p.

Drut, M. S., J. A. Crawford, and M. A. GregG. 1994. Brood habitat use by sage grouse in Oregon. Great Basin Naturalist 54:170-176.

Dunbar, M. R., M. A. Gregg, J. A. Crawford, M. R. Giordano, and S. J. Tornquist. 2005. Normal hematologic and biochemical values for pre-laying greater sagegrouse (Centrocercus urophasianus) and their influence on chick survival. Journal of Zoo and Wildlife Medicine 36:422-429.

Forslund, P., AND T. PÄrt. 1995. Age and reproduction in birds-hypotheses and tests. Trends in Ecology and Evolution 9:374-378.

Gardarsson, A., and R. Moss. 1969. Selection of food by Icelandic ptarmigan in relation to its availability and nutritive value. In: A. Watson [ED.]. Animal populations in relation to their food resources. The British Ecological Society Symposium 10:47-69.

Greeley, F. 1962. Effects of calcium deficiency on laying hen pheasant. Journal of Wildlife Management 26:186-193.

GregG, M. A. 1991. Use and selection of nesting habitat by sage grouse in Oregon [thesis]. Corvallis, OR, USA: Oregon State University. 46 p.

GREGG, M. A. 2006. Greater sage-grouse reproductive ecology: linkages among habitat resources, maternal nutrition, and chick survival [dissertation]. Corvallis, OR, USA: Oregon State University. 201 p.

Gregg, M. A., J. A. Crawford, M. S. Drut, and A. K. DeLong. 1994. Vegetational cover and predation of sage grouse nests in Oregon. Journal of Wildlife Management 58:162-166.

GregG, M. A., M. R. Dunbar, J. A. Crawford, and M. D. Pope. 2006. Total plasma protein and renesting by greater sage-grouse. Journal of Wildlife Management 70:472-478.

Gurchinoff, S., And W. L. Robinson. 1972. Chemical characteristics of jackpine needles selected by feeding spruce grouse. Journal of Wildlife Management 36:80-87.

HAGEN, C. A. 2005. Greater sage-grouse conservation assessment and strategy for Oregon: a plan to maintain and enhance populations and habitat. Salem, OR, USA: Oregon Department of Fish and Wildlife. 160 p.

Hannon, S. J., L. G. Sopuck, and F. C. Zwickel. 1982. Spring movements of female blue grouse: evidence for socially induced delayed breeding in yearlings. Auk 99:687-694.

Hanssen, I., J. Ness, and J. B. Steen. 1982. Paternal nutrition and chick production in captive willow ptarmigan (Lagopus lagopus). Acta Veterinaria Scandinavica 23:528-538.

Harms, R. H., B. L. Damron, and P. L. Waldroup. 1965. Influence of high phosphorus levels in caged layer diets. Poultry Science 44:1249.

Hinkson, R. S., JR., L. T. Smith, and A. G. Kese. 1970. Calcium requirement of the breeding pheasant hen. Journal of Wildlife Management 34:160-165.

HiRonaKa, H. 1985. Frequency approaches to monitor rangeland vegetation. In: Selected papers presented at the 38th Annual Meeting of the Society for Range Management; 11-15 February 1985; Salt Lake City, UT, USA. Denver, CO, USA: Society for Range Management. p. 84-86.

King, R. D., And J. F. Bendell. 1982. Foods selected by blue grouse (Dendragapus obscurus fuliginosus). Canadian Journal of Zoology 60:3268-3281.

Laycock, W. A., And D. A. Price. 1970. Factors influencing forage quality. In: Rangeland and wildlife habitat evaluation—a research symposium; May 1968; Flagstaff and Tempe, AZ, USA. Washington, DC, USA: US Department of Agriculture, Forest Service Miscellaneous Publication 1147. p. 37-47.

MARTIN, K. 1995. Patterns and mechanisms for age dependent reproduction and survival in birds. American Zoologist 35:340-348. 
Menge, H., L. T. Frobish, B. T. Weinland, and E. G. Geis. 1979. Effect of dietary protein and energy on reproductive performance on turkey hens. Poultry Science 58:419-426.

MorRison, M. L. 2001. A proposed research emphasis to overcome the limits of wildlife-habitat relationship studies. Journal of Wildlife Management 65:613-623.

Moss, R. 1969. A comparison of red grouse (Lagopus lagopus scoticus) stocks with the production and nutritive value of heather (Calluna vulgaris). Journal of Animal Ecology 38:103-122.

Moss, R. 1972. Food selection by red grouse (Lagopus lagopus scoticus [Lath.]) in relation to chemical composition. Journal of Animal Ecology 41:411-428.

Moss, R., and A. Watson. 1984. Maternal nutrition, egg quality, and breeding success of Scottish ptarmigan Lagopus mutus. Ibis 126:212-220.

Mrsterud, A., And R. F. Ims. 1998. Functional response in habitat use: availability influences relative use in trade-off situations. Ecology 79:1435-1441.

NayloR, B. J., AND J. F. Bendell. 1989. Clutch size and egg size of spruce grouse in relation to spring diet, food supply, and endogenous reserves. Canadian Journal of Zoology 67:969-980.

Pyle, W. H., and J. A. Crawford. 1996. Availability of foods of sage grouse chicks following prescribed fire in sagebrush-bitterbrush. Journal of Range Management 49:320-324.

Remington, T. E., and C. E. Braun. 1985. Sage grouse food selection in winter, North Park, Colorado. Journal of Wildlife Management 49:1055-1061.

RosentReter, R. 2005. Sagebrush identification, ecology, and palatability relative to sagegrouse. In: N. L. Shaw, M. Pellant, and S. B. Monsen [EDS.]. Sage-Grouse Habitat Restoration Symposium Proceedings; 4-7 June 2001; Boise, ID, USA. Fort Collins, CO, USA: US Department of Agriculture, Forest Service, Rocky Mountain Research Station, RMRS-P-38. p. 3-16.

SAS [computer program]. 2001. Version 8.02. Cary, NC, USA: SAS Institute.
SAVORY, C. J. 1975. Seasonal variations in the food intake of captive red grouse. British Poultry Science 16:471-479.

Sveum, C. M., J. A. Crawford, and W. D. Edge. 1998. Use and selection of broodrearing habitat by sage grouse in south-central Washington. Great Basin Naturalist 58:344-351.

Swanson, G. A., G. L. Krapu, J. C. Bartonek, J. R. Serie, and D. H. Johnson. 1974. Advantages in mathematically weighting waterfowl food habits data. Journal of Wildlife Management 38:302-307.

ThomAs, V. G. 1982. Energetic reserves of Hudson Bay willow ptarmigan during winter and spring. Canadian Journal of Zoology 60:1618-1623.

ThomAs, V. G. 1986. Body condition, ovarian hierarchies, and their relation to egg formation in Anseriform and Galliform species. Proceedings of the International Ornithological Congress 19:353-363.

Thomas, V. G., AND R. PopKo. 1981. Fat and protein reserves of wintering and prebreeding rock ptarmigan from south Hudson Bay. Canadian Journal of Zoology 59:1205-1211.

Western Regional Climate Center. 2005. Historical climate information, Western U.S. historical summaries (individual stations), Hart Mountain Refuge, Oregon; Sheldon, Nevada; Kings River Valley, Nevada. Available at: http:// www.wrcc.dri.edu. Accessed 17 April 2005.

Williams, J. B., D. BeSt, AND C. WARFoRD. 1980. Foraging ecology of ptarmigan at Meade River, Alaska. Wilson Bulletin 92:341-351.

Wrobleski, D. W., and J. B. Kauffman. 2003. Initial effects of prescribed fire on morphology, abundance, and phenology of forbs in big sagebrush communities in southeastern Oregon. Restoration Ecology 11:82-90.

Wunderle, J. M., JR. 1991. Age-specific foraging proficiency in birds. Current Ornithology 8:273-324. 